\title{
Ekonomik ve Politik Belirsizliğin Ekonomik Büyüme Üzerindeki Etkileri: G-7+BRC Ülkeleri Üzerine Bir Panel Veri Analizi (1997-2015)
}

\author{
The Effects of Economic and Political Uncertainty on Economic Growth: \\ A Panel Data Analysis on The G-7+BRC Countries (1997-2015)
}

\section{Ömer YALÇINKAYA ${ }^{1}$, Halil İbrahim AYDIN²}

\begin{abstract}
ÖZET
Bu çalışmada, ekonomik ve politik belirsizliklerin gelişmiş G-7 ve gelişmekte olan BRC (Brezilya, Rusya, Çin) ülkelerinin ekonomik büyüme performansları üzerindeki etkileri 19972015 dönemi için yeni nesil panel veri analizi metodolojisi kapsamında ekonometrik olarak incelenmektedir. Bu yönüyle çalışmada, ekonomik ve politik belirsizliklerin $\mathrm{G} 7+\mathrm{BRC}$ ülkelerinin ekonomik büyüme performansları üzerinde teorik çerçevede öngörüldüğü gibi bir etkiye sahip olup olmadığı ampirik açıdan değerlendirilmektedir. Çalışma sonucunda, inceleme döneminde G7+BRC ülkelerinde ekonomik ve politik belirsizliklerin ekonomik büyüme üzerindeki etkilerinin negatif yönlü ve istatistiki açıdan anlamlı olduğu tespit edilmiştir. Bu sonuçlar, gelişmiş G-7 ile gelişmekte olan BRC ülkelerinde 2008 ekonomik kriziyle birlikte ortaya çıkan ekonomik daralmaların devam etmesinde ve süreç içerisinde arzu edinilen toparlanmaların yakalanamamış olmasında, ekonomik ve politik gelişmelerden kaynakı belirsizliklerin de önemli bir rol oynadığını düşündürmektedir.
\end{abstract}

Anahtar Kelimeler: Ekonomik Büyüme, Ekonomik ve Politik Belirsizlikler Endeksi-EPU, Yeni Nesil Panel Veri Analizi.

\section{GiRiş}

Küresel ekonominin geleceğine ilişkin son zamanlarda ortaya çıkan gündemin özünde 2008 ekonomik krizinden itibaren aşılayamayan ve süreç içerisinde derinleşen ekonomik durgunluklar yatmaktadır. Nitekim 2008 ekonomik krizinden günümüze gelişmiş ülkeler başta olmak üzere gelişmekte olan ülkelerin birçoğunda uzun vadede dengeli ve sürdürülebilir

\begin{abstract}
In this study, the effects of economic and political uncertainties on economic growth performances of developed the G-7 and developing the BRC (Brazil, Russia, China) countries are examined econometrically in the context of the new generation panel data analysis methodology for the period 1997-2015. In the study this direction, it is empirically assessed whether economic and political uncertainties have an impact on the economic growth performances of the G7+BRC countries as predicted in the theoretical framework. As a result of the study, during the review period the effects of economic and political uncertainties on economic growth in G7 + BRC countries have been determined to be negative direction and statistically significant. These results suggest that the the economic contractions that emerged with the 2008 economic crisis in countries developed the G-7 with developing the BRC has been continued and the desired recovery has not been achieved in the process, uncertainties stemming from economic and political developments also play an important role.
\end{abstract}

Key Words: Economic Growth, Economic and Political Uncertainty Index-EPU, New Generation Panel Data Analysis. 
Avrupa Birliği üyeliğinden çıkma kararıyla (Brexit) birlikte mevcut jeopolitik risklerin ve siyasi belirsizliklerin daha da artması gibi süreç içerisinde yaşanan ekonomik ve politik gelişmeler bahse konu durumun muhtemel nedenleri arasında gösterilmektedir (TCKB, 2016).

Ulusal ve uluslararası düzeyde belirsizlik oluşturan bu türden ekonomik ve politik gelişmeler, piyasalardaki dalgalanmaları yükseltmekte, sermaye akımlarını tersine çevirmekte, dış finansmana ulaşım fırsatlarını kısıtlamakta ve iktisadi aktörlerin risk alma arzusunu azaltarak tüketim ve yatııım kararlarını sınırlandırmaktadır (TMB,2016). Bu bağlamda, yüksek düzeyli ekonomik ve politik belirsizliklerin ekonomik büyüme üzerindeki daraltıcı etkileri, tüketim, yatırım, istihdam ve risk primi gibi birbirini besleyen faklı kanallar yoluyla gerçekleşmektedir.

Tüketim, yatırım ve istihdam kararlarının geri alınması veya düzeltilmesi ilave maliyet yüklediğinden ekonomik ve politik belirsizliklerin yüksek olduğu bir makroekonomik ortamda, iktisadi aktörler belirsizlik giderilinceye ve daha fazla bilgi mevcut oluncaya kadar kararlarını ertelemeye yönelmektedir. Bununla beraber, yüksek düzeyli ekonomik ve politik belirsizlikler risk primini artırarak daha yüksek bir finansman maliyetini gerektirmekte ve daha düşük finansal varlık fiyatlarını ortaya çıkarmaktadır (Balta vd., 2013). Tüm bunlar, 2008 ekonomik krizinden itibaren gelişmiş ve gelişmekte olan ülkelerin birçoğunda, düşük düzeyde devam eden ekonomik büyüme oranlarındaki aşağı yönlü baskıları arttırmakta, daralan ekonomilerin genişlemesini geciktirmekte ve büyüyememe sorunsalına yapısal bir boyut kazandırmaktadır.

Bunların yanı sıra, süreç içerisinde genellikle gelişmiş ülkelerden kaynaklanan ekonomik ve politik belirsizliklerin daralan küresel likidite ve düşük emtia fiyatlarıyla birleşmesi gelişmekte olan ülkelere ilişkin riskleri daha fazla arttırmaktadır. Söz konusu ortamda artan dış finansman maliyetleri, cari açık sorunu yaşayan ve ulusal paraları özellikle $A B D$ Doları karşısında değer kaybeden ülkeler başta olmak üzere gelişmekte olan ülkelerin ekonomik büyüme görünümleri üzerindeki baskıları nispeten daha fazla hissettirmektedir (TMB, 2016). Bu bağlamda, gelişmiş ve gelişmekte olan ülkelerde 2008 ekonomik krizinin gün yüzüne çıkardığı ekonomik daralmaların hali hazırda devam etmesi ve süreç içerisinde arzu edilen toparlanmaların bir türlü yakalanamaması, ağırlıklı olarak ulusal ve uluslararası düzlemde meydana ge- len ekonomik ve politik belirsizliklere atfedilmektedir (Ermişoğlu ve Kanık, 2013; Wongi, 2016).

Bu noktadan hareketle çalışmada, ekonomik ve politik belirsizliklerin gelişmiş G-7 ve gelişmekte olan BRC (Brezilya, Rusya, Çin) ülkelerinin ekonomik büyüme performansları üzerindeki etkileri 1997-2015 dönemi için ekonometrik olarak incelenmektedir. Bununla birlikte çalışmada, ekonomik ve politik belirsizliklerin ekonomik büyüme üzerinde teorik çerçevede öngörüldüğü gibi bir etkiye sahip olup olmadığının ampirik açıdan da değerlendirilmesi amaçlanmaktadır. Bu yönüyle, gelişmiş ve gelişmekte olan ülke ekonomileri üzerinde yürütülen çalışmanın bulgularının bu konuda henüz yeni oluşmaya başlayan literatürün gelişimine katkı sağlayacağı düşünülmektedir.

Bu kapsamda, ikinci bölümde ekonomik ve politik belirsizlikleri konu edinen literatür ana hatlarıyla özetlenmektedir. Üçüncü bölümde, çalışmanın kapsamı açıklanmakta ve çalışmada kullanılan veri seti tanıtılmaktadır. Çalışmanın dördüncü bölümünde, araştırmanın metodolojisi kısaca açıklanmakta ve G-7+BRC ülkelerinde ekonomik ve politik belirsizliklerin ekonomik büyüme üzerindeki etkileri ekonometrik olarak incelenmektedir. Çalışma genel değerlendirmelerin yer aldığı dördüncü ve son bölümle birlikte tamamlanmaktadır.

\section{LITERATÜR ÖZETI}

İlgili literatürde ekonomik ve politik belirsizliklerin ekonomik büyüme üzerindeki etkilerini inceleyen çalışmalarda, konunun sadece ekonomik belirsizlik bağlamında ele alındığı ve ekonomik ve politik belirsizliklerin ekonomik büyüme üzerindeki etkilerinin eş-anlı olarak araştırılamadığı görülmektedir. Bu durumun oluşmasında, ekonomik ve politik belirsizliklerin tanımlanmasındaki ve ölçülmesindeki güçlüklerin yanı sıra ekonomik ve politik belirsizliklerin etkilerini birlikte ve bir bütün olarak ölçebilen göstergelerin son yıllara kadar temin edilebilmesindeki kısıtların da etkili olduğu belirtilmektedir (Ferrara ve Guérin, 2016). Bununla birlikte, ilgili literatürde ekonomik belirsizliklerin ekonomik büyüme üzerindeki etkilerini son yıllarda incelemeye başlayan çalışmalarda; ekonomik belirsizlikleri temsilen farklı nitelikteki makroekonomik ve özellikle finansal değişkenlerin kullanıldığı görülmektedir.

Bu kapsamda ekonomik belirsizliğin ekonomik büyüme üzerindeki etkilerini tespit etmek üzere yapılan çalışmalarda, ekonomik belirsizlikleri 
temsilen; enflasyon oranı, faiz oranı, döviz kuru vb. makroekonomik değişkenler ile hisse senedi fiyat endeksleri gibi finansal göstergelerden' ayrı ayrı ya da birlikte türetilen endeks şeklindeki göstergelerin düzey değerleri, değişimleri veya standart sapmaları kullanılmaktadır. Genellikle ABD ekonomisi üzerinde ve zaman serisi analizi kullanılarak yapılan çalışmalarda, ekonomik belirsizlikleri temsilen kullanılan makroekonomik ve/veya finansal göstergelerin çeşitli makroekonomik değişkenler ve/veya ekonomik büyüme üzerindeki etkileri inceleme konusu yapılmaktadır. Bu bağlamda, yapılan çalışmalarda, ekonomik belirsizliklerinin çeşitli makroekonomik değişkenler veya ekonomik büyüme üzerinde negatif yönlü ve istatistiki açıdan anlamlı (olumsuz) etkilere sahip olduğu sonucuna ulaşılmaktadır. (Dotsey ve Sarte (2000), Bloom (2009), Bachmann vd., (2013), Lovato (2013), Scotti (2013), Caggiano vd., (2014), Jurado vd., (2015), Rossi ve Sekhposyan (2015), Caggiano vd., (2017), Ferrara ve Guérin (2016)).

Diğer taraftan, ilgili literatür incelendiğinde ekonomik ve politik belirsizliklerin ekonomik büyüme üzerindeki etkilerinin birlikte ele alınmasının ise Baker vd., (2013) tarafından türetilen ekonomik ve politik belirsizlikler (EPU) endeksiyle olanaklı hale geldiği görülmektedir. Bu bağlamda, literatürde ekonomik ve politik belirsizliklerin ekonomik büyüme üzerindeki etkilerini tespit etmek üzere son yıllarda yapılan çalışmalarda genellikle Baker vd., (2013) tarafından türetilen ekonomik ve politik belirsizlikler (EPU) endeksinin kullanıldığı görülmektedir. Nitekim EPU endeksiyle, ekonomik ve politik açıdan belirsizlik yaratan olayların etkilerini aynı anda ve birlikte ölçülebilmesi mümkün olmaktadır (Baker vd., (2013). Baker vd., (2013) çalışmalarının ardından oluşmaya başlayan ampirik literatür incelendiğinde, yapılan çalışmaların bir bölümünde ekonomik ve politik belirsizliklerin (EPU), enflasyon, sanayi üretim endeksi, fiziksel sermaye yatırımları, istihdam, hisse senedi fiyatları gibi makroekonomik ve finansal göstergeler üzerindeki etkilerinin inceleme konusu yapıldığı görülmektedir. Ağırlıklı olarak $A B D$ ekonomisi üzerinde ve zaman serisi analizi kullanılarak yapılan bu çalışmalarda, ekonomik ve politik belirsizliklerin, makroekonomik ve finansal göstergeler üzerinde negatif yönlü ve istatistiki açıdan anlamlı (olumsuz) etkilere sahip olduğu sonucuna ulaşılmaktadır. (Benati (2013-ABD), Lovato (2013-ABD), Istrefi ve Piloiu $\left(2015^{2}\right)$, Baker vd., (2016-ABD)). Bununla birlikte, EPU endeksi kullanılarak ekonomik ve politik belirsizliklerin ekonomik büyüme üzerindeki eş-anlı etkilerini incelemek üzere yapılan istisnasız bütün çalışmalarda ekonomik ve politik belirsizliklerin ekonomik büyüme üzerinde negatif yönlü ve istatistiki açıdan anlamlı (olumsuz) etkilere sahip olduğu sonucuna ulaşılmaktadır. (Baker vd., (2013-ABD), Lovato (2013-ABD), Bhagat vd., (2013-Hindistan), Stockhammar ve Österholm (2014-İsveç), Baker vd., (2015-ABD), Stockhammar ve Österholm (20163)). Baker vd., (2016-ABD)).

\section{ARAŞTIRMANIN KAPSAMI VE VERILERi}

Çalışmanın bu bölümünde, ekonomik ve politik belirsizliklerin gelişsmiş G-7 ve gelişmekte olan BRC (Brezilya, Rusya, Çin) ülkelerinin ekonomik büyüme performansları üzerindeki etkileri 1997-2015 dönemi için ekonometrik olarak incelenmektedir. ${ }^{4}$ Bu kapsamda, çalışmada ekonomik ve politik belirsizliklerin ekonomik büyüme üzerindeki etkileri Baker vd., (2013) tarafından türetilen ekonomik ve politik belirsizlikler (EPU) endeksi yardımıyla araştııılmaktadır. EPU endeksi, gazetelerde ekonomik ve politik belirsizliklerle ilgili haberlerin sıklığı endeksi, süresi dolmak üzere olan vergi düzenlemeleri endeksi ve enflasyon ile kamu harcamaları beklentilerindeki dağılım endeksi şeklindeki üç alt endeksin birleşimiyle oluşturulmaktadır. Bu yönüyle EPU endeksi, ülke ekonomilerinde ekonomik ve politik gelişmelerin ortaya çıkardığı belirsizliklerin etkilerini eşanlı olarak ölçebilen/gözetebilen bir nitelikte hesaplanmaktadır. Başlangıçta sadece ABD için oluşturulan EPU endeksi, günümüzde Avrupa Birliği ülkeleri başta olmak üzere gelişmiş ve gelişmekte olan bir çok ülke için de hesaplanmaktadır ${ }^{5}$ (Baker vd., 2016). Ancak, ABD dışındaki diğer ülkeler için EPU endeksi sadece gazetelerdeki ekonomik ve politik belirsizliklerle ilgili haberlerin sıklığı alt endeksinin kullanılmasıyla hesaplanmaktadır. Çalışmada ekonomik ve politik belirsizlikler endeksinin, G-7+BRC ülkelerinin ekonomik büyüme performansları (kişi başına düşen Reel Gayri Safi Yurtiçi Hâsıla-GSYiH) üzerindeki etkilerini tespit etmek üzere tahmin edilecek modellerde kullanılan değişkenler Tablo 1'de açıklanmaktadır. 
Tablo 1: Modellerde Kullanılan Değişkenlerin Tanımlanması ${ }^{6}$

\begin{tabular}{|c|c|c|c|}
\hline \multicolumn{2}{|c|}{ İnceleme Dönemi: 2015-1997 } & \multicolumn{2}{|c|}{ Paneli Oluşturan Yatay Kesitlerin Sayısı: 10} \\
\hline $\begin{array}{l}\text { Değişkenin } \\
\text { Kısaltması }\end{array}$ & $\begin{array}{l}\text { Değişkenin } \\
\text { Tanımı }\end{array}$ & Veri Kaynağı & $\begin{array}{l}\text { Öngörülen } \\
\text { Etki }\end{array}$ \\
\hline RGSYIH & $\begin{array}{l}\text { Kişi Başına Düşen Reel GSYiH } 2011 \\
\text { (USD) }\end{array}$ & \multirow{2}{*}{$\begin{array}{l}\text { World Bank (WB) } \\
\text { (World Development } \\
\text { Indicators). }\end{array}$} & \\
\hline RSSER & $\begin{array}{l}\text { Reel Sabit Sermaye Yatırımları } 2010 \\
\text { (USD) }\end{array}$ & & $(+)$ \\
\hline EE & Eğitim Endeksi & $\begin{array}{l}\text { Penn World Table } \\
\text { (Version 9.0). }\end{array}$ & $(+)$ \\
\hline EPU & $\begin{array}{l}\text { Ekonomik ve Politik Belirsizlik } \\
\text { Endeksi }\end{array}$ & www.PolicyUncertainty.com. & $(-)$ \\
\hline Açıklama: & \multicolumn{2}{|c|}{$\begin{array}{l}\text { Tabloda tanımlanan bütün değişkenler, analizlerde inceleme } \\
\text { dönemindeki yıllık büyüme hızı değerleriyle kullanılmaktadır. }\end{array}$} & \\
\hline
\end{tabular}

Çalışmada, ekonomik ve politik belirsizliklerin ekonomik büyüme üzerindeki etkileri G-7+BRC ülkelerinin zaman serisi verilerinin birlikte kullanılmasından dolayı panel veri analiziyle incelenmekte ve seriler arasındaki ilişkilerin yönünün ve büyüklüğünün tespit edilmesi amaçlanmaktadır. Çalışmada, ekonomik ve politik belirsizliklerin ekonomik büyüme üzerindeki etkilerini tespit etmek üzere fiziki-beşeri sermaye birikimi kontrol değişkenleriyle birlikte tahmin edilecek ekonometrik model 1 numaralı eşitliklerde gösterilmektedir:

Model: $R G S Y I H_{i t}=a_{i t}+\beta_{1} R S S E R_{i t}+\beta_{2} E E_{i t}+\beta_{3} E P U+u_{i t}$

Modeldeki ( $\alpha$ ) terimi sabit parametreyi, $(\beta)$ terimi eğim parametrelerini, $(\mathrm{u})$ terimi hata terimini (i) alt indisi ülkeleri, (t) alt indisi ise periyot düzeyini temsil etmektedir.

\section{ARAŞTIRMANIN METODOLOJISI VE BULGULARI}

Çalışmada G-7+BRC ülkelerinde, ekonomik ve politik belirsizliklerin ekonomik büyüme üzerindeki etkilerini tespit etmek üzere eşitlikte tanımlan model, yatay kesit bağımlıı̆̆ını (YKB) göz önünde bulunduran panel veri metodolojisi kullanılarak sırasıyla dört aşamada araştırılmaktadır. Panel veri metodolojisinde serilerin durağanlık durumu önem taşımakta, durağan olmayan serilerle analiz yapıldığında sapmalı $t$, $F$ ve $\mathrm{R}^{2}$ test istatistik değerleriyle karşılaşılabilmektedir. $\mathrm{Bu}$ nedenle, panel veri çalışmalarında sahte regresyon olgusundan kaçınabilmek ve tutarlı sonuçlar elde edilebilmek için öncelikle serilerin durağanlık durumunun incelenmesi gerekmektedir (Tatoğlu, 2013). Panel verilerin durağanlığını belirlemek için kullanılacak birim kök testleri, paneli oluşturan birimlerde yatay kesit bağımlıı̆ının olup olmamasına göre birinci ve ikinci nesil şeklinde ikiye ayrılmaktadır. Birinci nesil panel birim kök testlerinde seriyi oluşturan kesitle- rden birinde meydana gelen şoktan tüm birimlerin eşit oranda etkilendikleri varsayılırken, ikinci nesil panel birim kök testlerinde ise seriyi oluşturan kesitlerden birinde meydana gelen şoktan her bir birimin farklı şekilde etkilendiği kabul edilmektedir. Bu kapsamda, paneli oluşturan birimler arasında YKB'nin olması durumunda seriyi oluşturan kesit birimlerin birbirinden bağımsız olduğunu varsayan birinci nesil panel birim kök testleri (Hadri 2000, Levin vd., 2002, Im vd., 2003, Breitung 2005 vb.,) tutarlı sonuçlar veremeyebilmekte ve seriyi oluşturan kesit birimlerin birbirine bağımlı olduğunu varsayan (Taylor ve Sarno 1998, Breuer vd., 2002, Pesaran 2007, Hadri ve Kurozumi, 2012 vb.,) varsayan ikinci nesil panel birim kök testlerinin kullanılması gerekmektedir (Göçer vd., 2012). Bu nedenle, panel veri çalışmalarında model tahminlerine başlanılmadan önce modeldeki serilerde/modelin eş-bütünleşme denkleminde YKB'nin araştırılması ve analizlerde kullanılacak birim kök ile diğer ardıl testlerin tespit edilmesi gerekmektedir. Bu durum dikkate alınmadığında kullanılan testler güvenilir sonuçlar veremeyebilmektedir (Pesaran, 2004; Menyah vd., 2014).

Bununla birlikte, panel verilerde yatay kesit bağımlıı̆ı araştırılırken serinin zaman ve kesit boyu- 
tunun birlikte dikkate alınması gerekmektedir. Pesaran vd., (2008) tarafından geliştirilen CD-LM adj testi, serinin zaman boyutunun kesit boyutundan büyük olduğu $(T>N)$, küçük olduğu $(T<N)$ ve serinin zaman boyutunun kesit boyutuna eşit olduğu $(T=N)$ tüm durumlarda kullanılabilmektedir. Nitekim düzeltilmiş CD-LM testi olarak adlandırılan CD-LM adj testinde, test istatistiğine yatay kesitlerin ortalaması $\left(\mu_{\text {Tij }}\right)$ ( ile varyansı $\left(U_{T i j}\right)$ (eklendiğinden test istatistiği bireysel ortalamanın sıfırdan farklı olduğu bütün durumlarda tutarlı sonuçlar verebilmektedir (Pesaran vd., 2008). CD-LM ${ }_{\text {adj }}$ testinde yatay kesit bağımsızlığının varlığı "seride veya modelde yatay kesit bağımlılığı yoktur" temel hipotezine karşlık, "seride veya modelde yatay kesit bağımlıı̆̆ı vardır" şeklindeki alternatif hipoteziyle araştırılmaktadır. Asimtotik olarak standart normal dağılım gösterdiği varsayılan CD-LM ${ }_{\text {adj }}$ testinde, temel hipotezin reddedilmesi durumunda seride ve/veya modelde YKB'nin bulunduğu sonucuna ulaşılmaktadır. Çalışmada, tanımlanan modeldeki serilerde ve modelin eş-bütünleşme denkleminde yatay kesit bağımlılığının varlığı CD-LM adj testiyle incelenmekte ve sonuçları Tablo 2'de gösterilmektedir.

Tablo 2: Yatay Kesit Bağımlılı̆ı̆ Sınama Testi Sonuçları

\begin{tabular}{|c|c|c|}
\hline Değişkenler & CD-LM $_{\text {adj }}$ Test İstatistiği & L \\
\hline RGSYiH & $63.54^{* * *}[0.000]$ & 2 \\
\hline RSSER & $36.62^{* * *}[0.000]$ & 3 \\
\hline EE & $\left.50.59^{* *} 0.000{ }^{*}\right]$ & 2 \\
\hline EPU & $18.94^{* *}[0.000]$ & 4 \\
\hline Model & $1.98^{* *}[0.024]$ & 3 \\
\hline
\end{tabular}

Not: Sabitli+Trendli formlardan elde edilen CD-LM ${ }_{\text {adj }}$ test istatistiklerinin önündeki $\left(^{* * *}\right)$ ve $\left(^{* *}\right)$ işaretleri serilerde ve eşbütünleşme denkleminde sırasıyla $\% 1$ ve $\% 5$ anlamlılık düzeyinde yatay kesit bağımlılığının bulunduğu anlamına gelmektedir. Tablodaki "L" sütunu değişkenler ve eş bütünleşme denklemleri için Schwarz bilgi kriterleri eşliğinde belirlenen optimal gecikme uzunluklarını ve "[ ]" parantez içindeki değerler test istatistiklerine ait olasılık değerlerini göstermektedir.

Tablo 2'deki sonuçlar incelendiğinde, tanımlı modeldeki tüm değişkenler ve modelin eş-bütünleşme denklemi için hesaplanan CD-LM ${ }_{\text {adj }}$ test istatistiklerine ait olasılık değerlerinin 0.05 'den küçük olduğu görülmektedir. Bu durumda, G-7+BRC ülkelerinde değişkenler ve eş-bütünleşme denklemi için
$C D-L M_{a d j}$ testlerine göre oluşturulan temel hipotezlerin reddedilmesi gerekmektedir. Bu sonuçlar, ilgili ülke grubunda paneli oluşturan yatay kesit birimler arasında tanımlı modeldeki değişkenler ve eş-bütünleşme denklemi açısından yatay kesit bağımlılığının bulunduğunu göstermektedir. Bununla birlikte, sonuçlar, analizlerin izleyen aşamalarında YKB'nin varlığını dikkate alan yeni nesil panel veri metodolojisi test metodlarının kullanılmasının gerektiğine işaret etmektedir (Baltagi, 2008).

$\mathrm{Bu}$ kapsamda, G-7+BRC ülkelerinde tanımlı modeldeki serilerin durağanlık koşulu, YKB'yi dikkate alan ve Pesaran (2007) tarafından geliştirilen CADF (Cross-sectional Augmented Dickey Fuller) ikinci nesil panel birim kök testiyle araştırılmaktadır. Söz konusu teste ilk olarak paneli oluşturan tüm yatay kesitler için CADF test istatistik değerleri hesaplanmakta, akabinde bu değerlerin aritmetik ortalaması alınarak panel geneli için CIPS (Cross-Sectionally Augmented IPS) istatistikleri bulunmaktadır. N $>$ T koşulu için tasarlanmış olan ve $\mathrm{N}<\mathrm{T}$ koşulunda da anlamlı sonuçlar verebilen CADF test istatistikleri aşağıdaki gibi hesaplanmaktadır:

$$
t(N, T)=\frac{\Delta y_{i}^{\prime} \bar{M}_{i} y_{i-1}}{\bar{\sigma}^{2}\left(\Delta y_{i-1}^{\prime} \bar{M}_{i} y_{i-1}\right)^{1 / 2}}
$$

Eşitlik 2'de verildiği gibi CADF test istatistik değerleri hesaplandıktan sonra bu değerlerin ortalaması alınarak CIPS istatistik değerleri de aşağıdaki gibi elde edilmektedir.

$$
C I P S=N^{-1} \sum_{i=1}^{n} t(N, T)
$$

Hesaplanan CADF ve CIPS test istatistiği değerleri Pesaran (2007) tarafından Monte Carlo simülasyonları ile oluşturulan kritik tablo değerleriyle karşılaştırılmakta ve durağanlık için hipotezler sınanmaktadır. Test sonucunda, hesaplanan CADF ve CIPS test istatistik değerlerinin kritik tablo değerlerinden mutlak değerce büyük olması durumunda temel hipotez (seride birim kök vardır) reddedilmekte ve ilgili birim-panel geneli için alternatif hipotez (seride birim kök yoktur) kabul edilmektedir (Pesaran, 2007). Çalışmada tanımlanan modeldeki değişkenlerin durağanlık durumu, CIPS Panel Birim Kök testiyle araştırılmakta ve sonuçları Tablo 3'te sunulmaktadır. 
Tablo 3: CIPS Panel Birim Kök Testi Sonuçları

\begin{tabular}{|c|c|c|c|}
\hline Değişkenler & Seviye & 1. Fark & L \\
\hline RGSYiH & -1.79 & $-3.54^{* * *}$ & 2 \\
\hline RSSER & -1.89 & $-3.18^{* * *}$ & 3 \\
\hline EE & -1.83 & $-3.68^{* * *}$ & 2 \\
\hline EPU & -1.97 & $-3.24^{* * *}$ & 4 \\
\hline \multirow{2}{*}{ CIPS Kritik Tablo Değerleri } & $\mathbf{( \% ~ 1 )}$ & $\mathbf{( \% ~ 5 )}$ \\
\cline { 2 - 4 } & $\mathbf{- 3 . 1 5}$ & $\mathbf{- 2 . 8 8}$ \\
\hline
\end{tabular}

Not: Sabitli+Trendli formlardan elde edilen CIPS istatistiklerinin önündeki $\left(^{* * *}\right)$ işareti değişkenlerin $\% 1$ anlamlılık düzeyinde durağan olduklarını göstermektedir. CIPS istatistiği kritik tablo değerleri T ve N durumlarına göre Pesaran (2007) çalışmasından alınmıştır. "L" sütunu hakkında bakınız: Tablo 2.

Tablo 3'teki sonuçlar incelendiğinde, G-7+BRC ülkelerinde tanımlı modeldeki tüm değişkenlerin \% 5 anlamlılık düzeyine göre seviye değerinde durağan olmadıkları görülmektedir. Değişkenlerin birinci farkları alındığında ise G-7+BRC ülkeleri için tanımlı modeldeki bütün değişkenlerin, \% 1 anlamlılık düzeyinde durağan hale geldikleri görülmektedir. Bu durum, değişkenler için sabitli+trendli formlarda hesaplanan CIPS istatistik değerlerinin kritik tablo değerlerinden 0.01 önem düzeyinde mutlak değerce büyük olmasından ve temel hipotezlerin reddedilmesinden anlaşılmaktadır.

Tanımlanan modelde kullanılan tüm değişkenlerin CADF Panel Birim Kök testine göre birinci farklarında durağan olduğu belirlendikten sonra (sonuçların tutarlığını tespit etmek üzere) sahte birim köke sebebiyet verilmemesi için serilerin durağanlık koşulu Hadri ve Kuruzomi (2012) tarafından geliştirilen panel birim kök testiyle de incelenmektedir (Sağlam vd., 2017). Hadri-Kurozumi (2012) Panel Birim Kök Testinde, paneldeki yatay kesitler arasındaki bağımlılık ve heterojen yapı dikkate alınmakta ve seriyi oluşturan ortak faktörlerden kaynaklanan birim kökün varlığı da göz önünde bulundurmaktadır. Hadri-Kurozumi (2012) Panel Birim Kök Testinde, panel genelinde birim kökün varlığı $\left(Z_{A}^{S P C}\right)$ ile $\left(Z_{A}^{L A}\right)$ şeklindeki normal dağılıma sahip oldukları varsayılan test istatistikleriyle ve "seride birim kök bulunmamaktadır" temel hipotezine karşlık "seride birim kök bulunmaktadır" şeklindeki alternatif hipotezle araştırılmaktadır (Hadri ve Kurozumi, 2012). Çalışmada tanımlanan modeldeki değişkenlerin durağanlık durumu panel geneli için ayrıca Hadri-Kuruzomi (2012) Panel Birim Kök Testiyle incelenmekte ve sonuçları Tablo 4'te raporlanmaktadır.
Tablo 4: Hadri-Kuruzomi Panel Birim Kök Testi

\begin{tabular}{|c|c|c|c|c|c|}
\hline & \multicolumn{2}{|c|}{ Seviye } & \multicolumn{2}{c|}{ 1. Fark } & \multirow{2}{*}{$\mathrm{L}$} \\
\cline { 1 - 5 } Değişkenler & $\left(Z_{A}^{S P C}\right)$ & $\left(Z_{A}^{L A}\right)$ & $\left(Z_{A}^{S P C}\right)$ & $\left(Z_{A}^{L A}\right)$ & \\
\hline RGSYiH & 16.81 & 14.23 & $-1.12^{* *}$ & $1.21^{* *}$ & 4 \\
\hline RSSER & 11.05 & 23.35 & $0.26^{* *}$ & $0.96^{* *}$ & 3 \\
\hline EE & 5.70 & 1.80 & $0.09^{* *}$ & $-1.49^{* *}$ & 2 \\
\hline EPU & 2.99 & 3.72 & $1.51^{* *}$ & $-1.49^{* *}$ & 2 \\
\hline
\end{tabular}

Not: Tablodaki " $L$ ” sütununda gösterilen değişkenler için optimum gecikme uzunlukları Schwarz bilgi kriteri eşliğinde belirlenmiştir. Sabitli+Trendli formlardan elde edilen test istatistiklerinin önündeki $(* *)$ işareti değişkenler için temel hipotezlerin \% 5 anlamlılık düzeyinde kabul edildiğini göstermektedir.

Tablo 4'deki Hadri-Kuruzomi Panel Birim Kök Testi sonuçları incelendiğinde, $\left(Z_{A}^{S P C}\right)$ ve $\left(Z_{A}^{L A}\right)$ test istatistiklerine göre tüm değişkenlerin \% 5 önem düzeyinde seviye değerinde durağan olmadıkları görülmektedir. Bu nedenle, bütün değişkenlerin birinci farklarının alınması yoluna gidilmiş ve değişkenlerin birinci farkları alındığında tanımlı modeldeki tüm değişkenlerin her iki test istatistiğine göre de $\% 5$ anlamlılık düzeyine göre durağan hale geldiği belirlenmiştir.

Bu durum, değişkenler için $\left(Z_{A}^{S P C}\right)$ ve $\left(Z_{A}^{L A}\right)$ test istatistiklerine göre oluşturulan temel hipotezlerin \% 5 önem düzeyinde kabul edilmesinden anlaşılmaktadır.

Diğer taraftan, seviyede değil birinci farklarında durağanlaştıkları belirlenen serilerdeki fark alma süreci, serilerde geçmiş dönemlerde meydana gelmiş olabilen kısa süreli geçici şokların etkisini ve bu seriler arasında uzun dönemde olması muhtemel bütünleşik ilişkileri yok edebilmektedir. Bu nedenle, iktisadi seriler durağan olmasalar bile bu serilerin durağan bir bileşimi bulunabilmekte ve bu durum eş-bütünleşme analizleriyle belirlenebilmektedir (Tarı, 2010). YKB'nin bulunmadığı modellerde (Johansen 1988, Pedroni 1999, Kao 1999 vb.,) birinci nesil panel eş-bütünleşme testleri kullanılabilirken, eş-bütünleşme denkleminde yatay kesit bağımlılığının varlığı durumunda, değişkenler arasındaki uzun dönemli ilişkiler yatay kesit bağımlılığına izin veren (Westerlund ve Edgerton 2007, Westerlund 2008 vb.,) ikinci nesil panel eş-bütünleşme testleriyle incelenebilmektedir.

$\mathrm{Bu}$ çalışmada kullanılan Westerlund (2008) Durbin-Hausman Panel Eş-Bütünleşme testinde, uzun dönemde eş-bütünleşik ilişkiler $\mathrm{DH}$ panel $\left(\mathrm{DH}_{\mathrm{p}}\right)$ ve $\mathrm{DH}$ grup $\left(\mathrm{DH}_{\mathrm{g}}\right)$ test istatistikleriyle panel ve grup boyutunda eş anlı olarak incelenebilmektedir. $\left(\mathrm{DH}_{\mathrm{p}}\right)$ ve $\left(\mathrm{DH}_{\mathrm{g}}\right)$ testleri, paneli oluşturan bütün yatay kesit birimler 
arasında otoregresif parametrenin sırasıyla aynı olduğu ve farklılaştığı varsayımına dayanmaktadır. Bu kapsamda, $\left(\mathrm{DH}_{\mathrm{p}}\right)$ ve $\left.\mathrm{DH}_{\mathrm{g}}\right)$ testlerinde temel hipotezin reddedilmesi durumunda, sırasıyla paneli oluşturan bütün yatay kesit birimlerde ve paneli oluşturan yatay kesit birimlerin en azından bazılarında eş-bütünleşme ilişkisinin bulunduğu kabul edilmektedir. Bununla beraber, her iki testte de temel hipotezlerin kabul veya red edilmesine hesaplanan test istatistik değerlerinin normal dağılım kritik tablo değerleriyle karşılaştııılmasıly karar verilmektedir. Hesaplanan $\mathrm{DH}_{\mathrm{p}}$ ve $\mathrm{DH}_{\mathrm{g}}$ test istatistik değerlerinin kritik tablo değerinden (2.33) büyük olması durumunda temel hipotezler reddedildiğinden, paneli oluşturan bütün kesitlerde ve/veya paneli oluşturan bazı kesitlerde $\% 1$ önem düzeyinde eş-bütünleşme ilişkilerinin bulunduğuna karar verilmektedir (Westerlund, 2008). Çalışmada, tanımlanan modeldeki değişkenler arasında uzun dönemli ilişkilerinin varlığı Durbin-Hausman Panel Eş-Bütünleşme testiyle araştırılmakta ve sonuçları Tablo 5'te sunulmaktadır.

Tablo 5: Durbin-Hausman Panel Eş-Bütünleşme Test Sonuçları

\begin{tabular}{|c|c|c|c|}
\hline Test İstatistikleri & $\mathbf{D H}_{\mathbf{g}}$ & $\mathbf{D H}_{\mathbf{p}}$ & $\left(\widetilde{\Delta}_{a d j}\right)$ \\
\hline Model & $3.07^{* * *}$ & $4.35^{* * *}$ & $0.3907^{* * * *}$ \\
& {$[0.000]$} & {$[0.000]$} & {$[0.348]$} \\
\hline Kritik Değerler (\% 1) & 2.33 & 2.33 & \\
\hline
\end{tabular}

Not: $\mathrm{DH}_{\mathrm{p}}$ ve $\mathrm{DH}$ test istatistikleri sabitli+trendli formdan ve olasılık değerleri (10.000 döngülü) bootstrap dağılımından elde edilmişstir. $\left.{ }^{* * *}\right)$ işareti \% 1 anlamlılık düzeyinde modeldeki seriler arasında eş-bütünleşme ilişkisinin bulunduğunu göstermektedir. $\left(\widetilde{\Delta}_{a d j}\right)$ test istatistiklerinin önündeki ${ }^{(* * *}$ * $)$ işareti eş-bütünleşme denklemindeki eğim katsayılarının \% 1 anlamlılık düzeyinde homojen olduğunu belirtmektedir. "[ ]" köşeli parantez içindeki sayılar test istatistiklerine ait olasılık değerlerini göstermektedir.

Tablo 5'teki sonuçlar incelendiğinde, G-7+BRC ülkelerinde tanımlı modelde $\mathrm{DH}_{\mathrm{p}}$ ve $\mathrm{DH}_{\mathrm{g}}$ test istatistiklerine göre \% 1 önem düzeyinde temel hipotezlerin reddedildiği görülmektedir. Bu sonuçlar, G-7+BRC ülkeleri için tanımlı modelde panel geneli ile paneli oluşturan bütün yatay kesit birimlerde seriler arasında uzun dönemli bir eş-bütünleşme ilişkisinin olduğunu göstermektedir.

Tanımlı modeldeki seriler arasında uzun dönemli ilişkilerin belirlenmesinin ardından, eş-bütünleşme denklemindeki eğim katsayılarının yatay kesit birimler arasındaki homojenlik veya heterojenlik durumu Pesaran vd., (2008) Eğim Katsayılarının Homojenliği (Slope Homogeneity Tests) testiyle araştırılabilme- ktedir. Eğim Katsayılarının Homojenliği testinde, modellerin eş-bütünleşme denklemlerindeki eğim katsayılarının yatay kesit birimlere göre farklılık gösterip göstermediği $\left(\widetilde{\Delta}_{a d j}\right)$ test istatistikleriyle "eğim katsayıları homojendir" şeklindeki temel hipoteze karşııık "eğim katsayıları homojen değildir" alternatif hipoteziyle analiz edilmektedir.

Hesaplanan $\left(\widetilde{\Delta}_{a d j}\right)$ test istatistiklerinin olasılık değerlerinin 0.01 'den büyük olması halinde temel hipotez \% 1 anlamlılık düzeyine göre kabul edilmekte ve eş-bütünleşme katsayılarının yatay kesit birimler arasında homojen olduğu sonucuna ulaşılmaktadır (Pesaran vd., 2008). Çalışmada tanımlanan modelin eş-bütünleşme denklemindeki eğim katsayılarının homojenliği $\left(\widetilde{\Delta}_{a d j}\right)$ testiyle incelenerek sonuçları Tablo 5'te gösterilmektedir. Tablo 5'teki sonuçlar incelendiğinde, tanımlı model için hesaplanan $\left(\widetilde{\Delta}_{a d j}\right)$ test istatistikleri olasılık değerlerinin 0.01 'ten büyük olduğu görülmektedir. Bu durum, tanımlı modelin eş-bütünleşme denklemindeki, sabit terim ile eğim katsayılarının yatay kesit birimler arasında homojen olduğunu ve panel genelindeki uzun dönemli eş-bütünleşik ilişkilerin geçerli olduğunu belirtmektedir.

G-7+BRC ülkeleri için tanımlı modelde bulunan seriler arasındaki uzun dönemli ilişkiler eş-bütünleşme testleriyle saptandıktan sonra serilere ait uzun dönem katsayılarının nasıl tahmin edilmesi gerektiğinin belirlenmesi gerekmektedir. Çalışmada tanımlanan modelin eş-bütünleşme denkleminde YKB bulunduğundan, modeldeki açıklayıcı değişkenlerin bağımlı değişken üzerindeki uzun dönemli etkilerinin büyüklüğü YKB'yi dikkate alan tahmincilerle incelenebilmektedir. Bu kapsamda, G-7+BRC ülkelerinde panel geneli için uzun dönemli katsayıların elde edilmesinde YKB'yi dikkate alan Eberhardt ve Bond (2009) tarafından geliştirilen Panel AMG (Augmented Mean Group) tahmincisi kullanılmaktadır. Panel AMG tahmincisinde panel geneli için uzun dönemli eş-bütünleşme katsayıları, yatay kesit birimlerin uzun dönemli eş-bütünleşme katsayılarının aritmetik ortalamalarının ağırlıklandırılmasıyla hesaplanmaktadır. Panel AMG tahmincisi, değişkenlerdeki ortak faktörleri ve dinamik etkileri dikkate almakta ve içsellik probleminin olması durumunda da etkin sonuçlar türetebilmektedir (Eberhardt ve Bond, 2009). Çalışmada G-7+BRC ülkelerinde ekonomik ve politik belirsizliğin ekonomik büyüme üzerindeki uzun dönemli etkilerini tespit etmek üzere kurulan 
model Panel AMG yöntemiyle tahmin edilmekte ve sonuçları Tablo 6'da gösterilmektedir.

Tablo 6: Modellere Ait Tahmin Sonuçları: Panel AMG

\begin{tabular}{|c|c|c|}
\hline \multicolumn{3}{|c|}{ Bağımlı Değişken: RGSYiH } \\
\hline & Katsayı & SE. \\
\hline RSSER & $0.2316^{* * *}$ & $0.0393[0.000]$ \\
\hline EE & $0.4409^{* *}$ & $0.2150[0.043]$ \\
\hline EPU & $-0.0044^{* *}$ & $0.0020[0.024]$ \\
\hline Sabit Terim (C) & $0.9864^{* * *}$ & $0.2347[0.000]$ \\
\hline
\end{tabular}

Not: Modeldeki değişkenler için hesaplanan katsayıların önündeki $\left.{ }^{(* * *}\right)$ ve $\left(^{* *}\right)$ işaretleri, katsayılara ait t-istatistiklerinin sırasıyla $\% 1$ ve \% 5 önem düzeyinde anlamlı olduğunu belirtmektedir. Tablodaki SE terimi, katsayılara ait standart hataları ve "[ ]" parantez içindeki değerler de katsayılara ait olasılık değerlerini belirtmektedir.

Tablo 6'daki tahmin sonuçları incelendiğinde, G-7+BRC ülkelerinde beklentilerle uyumlu olarak RSSER ve EE açıklayıcı değişkenlerinin katsayılarının pozitif yönlü ve istatistiki açıdan $\% 1$ ve $\% 5$ önem düzeyinde anlamlı olduğu görülmektedir. Bununla birlikte Tablo 6'daki model sonuçları değişkenlerin katsayıları açısından analiz edildiğinde, RSSER ve EE açıklayıcı değişkenlerinin katsayılarının sırasıyla (0.2316) ve (0.4409) olarak hesaplandığı görülmektedir. Bu sonuçlar, ilgili ülke grubunda fiziksel ve beşeri sermaye birikiminde meydana gelen bir birimlik (bir dolarlık) bir artışın ekonomik büyüme üzerinde sırasıyla 0.23 ve 0.44 birimlik bir artış meydana getirdiğini göstermektedir. Bu durum, ilgili ülke grubunda bir yandan fiziksel ve beşeri sermaye birikiminin ekonomik büyüme üzerindeki etkilerinin pozitif yönlü ve istatistiki açıdan anlamlı olduğunu göstermekte diğer yandan da eğitim seviyesi dikkate alındığında beşeri sermaye birikiminin ekonomik büyüme üzerindeki söz konusu etkilerinin büyüklüğünün yaklaşık iki kat daha fazla olduğunu ortaya koymaktadır.

Buna karşılık, Tablo 6'daki tahmin sonuçları EPU değişkeni açısından incelendiğinde, G-7+BRC ülkelerinde beklenildiği gibi EPU açıklayıcı değişkeninin katsayısının (-0.0044) negatif yönlü ve istatistiki açıdan \% 5 önem düzeyinde anlamlı olduğu görülmektedir. Bu sonuçlar, ilgili ülke grubunda ekonomik ve politik belirsizlik endeksi düzeyinde meydana gelen bir birimlik bir artışın ekonomik büyüme üzerinde 0.0044 birimlik (dolarlık) bir azalış meydana getirdiğini göstermektedir. Bu sonuçlar, inceleme döneminde G-7+BRC ülkelerinde, ekonomik ve politik belirsizlik düzeyinde meydana gelen artışların teorik-ampirik çerçevede öngörüldüğü gibi ekonomik büyümeyi negatif yönlü ve istatistiki açıdan anlamlı bir şekilde etkilediğini ortaya koymaktadır. Diğer yandan, ekonomik ve politik belirsizlik endeksi düzeyinde meydana gelen artışların ekonomik büyüme üzerindeki olumsuz etkilerinin büyüklüğünün diğer değişkenlere kıyasla nispeten düşük kalması, paneli oluşturan yatay kesitler içerisinde gelişmiş ülkelerin çoğunlukta olması ve bunların panel genelindeki katsayıları baskılamasından kaynaklanabileceğini düşündürmektedir. Nitekim ekonomik ve politik ortamın görece istikrarlı olduğu gelişmiş G-7 ülkelerinde gelişmekte olan BRC ülkelerine kıyasla ekonomik ve politik belirsizliklerin ekonomik büyüme süreçleri üzerindeki negatif yönlü etkilerinin daha az hissedilebilir olacağı öngörülmektedir.

\section{SONUÇ}

Bu çalışmada, ekonomik ve politik belirsizliklerin gelişmiş G-7 ve gelişmekte olan BRC (Brezilya, Rusya, Çin) ülkelerinin ekonomik büyüme performansları üzerindeki etkileri 1997-2015 dönemi için ekonometrik olarak analiz edilmektedir. Bu yönüyle çalışmada, ekonomik ve politik belirsizliklerin ekonomik büyüme üzerinde teorik çerçevede öngörüldüğü gibi bir etkiye sahip olup olmadığının ampirik açıdan da değerlendirilmesi hedeflenmektedir. Çalışmada, G-7+BRC ülkelerinde ekonomik ve politik belirsizliklerin ekonomik büyüme üzerindeki etkilerini incelemek üzere fiziki ve beşeri sermaye kontrol değişkenleriyle kurulan model yatay kesit bağımlılığını dikkate alan yeni nesil panel veri metodolojisi kapsamında tahmin edilmektedir. Uygulama sonucunda, G-7+BRC ülkeleri için tanımlanan modelden elde edilen teorik yazınla ve ampirik literatürle uyumlu olduğu belirlenen sonuçları şu şekilde ifade etmek mümkün olmaktadır.

G-7+BRC ülkelerinde fiziksel sermaye birikimi ile beşeri sermaye birikimini temsilen kullanılan göstergelerin ekonomik büyüme üzerindeki etkilerinin pozitif yönlü ve istatistiki açıdan anlamlı olduğu sonucuna ulaşılmıştır. Bahse konu sonuçlar çalışma döneminde, G-7+BRC ülkelerinde, fiziksel sermaye birikiminde ve eğitim düzeyi dikkate alındığında beşeri sermaye birikiminde meydana gelen artışların/ iyileşmelerin ekonomik büyümeyi pozitif ve istatistiki açıdan anlamlı bir şekilde etkilediğini göstermektedir.

Bunların yanı sıra, G-7+BRC ülkelerinde, ekonomik ve politik belirsizlikleri temsilen kullanılan EPU endeksinin ekonomik büyüme üzerindeki etkilerinin negatifyönlü ve istatistiki açıdan anlamlı olduğu belir- 
lenmiştir. Söz konusu sonuçlar inceleme döneminde G-7+BRC ülkelerinde ekonomik ve politik belirsizlik düzeyinde meydana gelen artışların teorik-ampirik çerçevede öngörüldüğü gibi ekonomik büyümeyi negatif ve istatistiki açıdan anlamlı bir şekilde etkilediğini göstermektedir.

Çalışmadan elde edilen tüm bu sonuçlar, gelişmiş G-7ilegelişmekte olan BRCülkelerinde 2008 ekonomik kriziyle birlikte ortaya çıkan ekonomik daralmaların devam etmesinde ve süreç içerisinde arzu edinilen toparlanmaların yakalanamamış olmasında diğer şartlar sabitken ekonomik ve politik gelişmelerden kaynaklı belirsizliklerin de önemli bir rol oynadığına işaret etmektedir. Bu noktada, G-7+BRC ülkelerinde politika yapıcıları tarafından iktisadi dengelemenin en önemli bileşenlerinden olan belirsizlik ortamını ortadan kaldırıcı politikaların geliştirilip uygulanması gereklilik arz etmektedir. Böylelikle G-7+BRC ülkelerinde, iç ve dış gelişmelerin etkisiyle meydana gelen ekonomik ve politik belirsizliklerin ekonomik büyüme üzerindeki olumsuz etkilerinin belli bir ölçüde azaltılabilmesi ve ekonomik açıdan arzu edinilen toparlanmaların yakalanabilmesi mümkün olabilecektir. Öte taraftan, ekonomik ve politik belirsizliklerin ekonomik büyüme üzerindeki etkilerini tespit etmek için EPU endeksinin kullanılmasıyla yapılacak ampirik çalışmalarda, verilerinin ulaşılabilir olması durumunda daha fazla sayıda ülkenin kapsanmasının bu konuda henüz yeni oluşmaya başlayan literatürün gelişimine katkı sağlayacağı düşünülmektedir.

\section{KAYNAKÇA}

Baker, S. R., Bloom, N. ve Davis, S. J. (2013) “Measuring Economic Policy Uncertainty", Stanford University Working Paper.

Baker, S. R., Bloom, N. ve Davis, S. J. (2015) “Measuring Economic Policy Uncertainty." National Bureau of Economic Research NBER Working Paper No: 21633.

Baker, S. R., Bloom, N. ve Davis, S. J. (2016) “Measuring Economic Policy Uncertainty", Quarterly Journal of Economics, 131(4): 1539-1636.

Balta, N., Fernández, I.V.ve Ruscher, E. (2013)“Assessing the Impact of Uncertainty on Consumption and Investment", Quarterly Report on the Euro Area, 12(2): 7-16.

Baltagi, B. H. (2008) Econometric Analysis of Panel Data, Fourth Edition, West Sussex: John Wiley \& Sons.

Benati, L. (2013) "Economic policy uncertainty and the great recession", University of Bern, mimeo. Cerca con Google. http://www.policyuncertainty.com/ media/Uncertainty_Benati.pdf

Bhagat, S., Ghosh, P. ve Rangan, S.. P. (2013) "Economic Policy Uncertainty and Economic Growth in India", Indian Institute of Management Bangalore, Working Paper No:407.

Bloom, N. (2009) "The Impact of Uncertainty Shocks", Econometrica, 77(3): 623-685.

Breitung, J. (2005) "A Parametric Approach to The Estimation of Cointegration Vectors in Panel Data", Econometric Reviews, 24(2): 151-173.

Breuer, J. B., Mcnown, R. ve Wallace, M. (2002) “Seriesspecific Unit Root Tests with Panel Data", Oxford Bulletin of Economics and Statistics, 64(5): 527-546.
Caggiano, G., Castelnuovo, E. ve Figueres, J. M. (2017) "Economic policy uncertainty and unemployment in the United States: A nonlinear approach", Economics Letters, 151, 31-34.

Caggiano, G., Castelnuovo, E. ve Groshenny, N. (2014) "Uncertainty Shocks and Unemployment Dynamics: An Analysis of Post-WWII U.S. Recessions", Journal of Monetary Economics, 67, 78-92.

Dotsey, M. ve Sarte, P. D. (2000) "Inflation uncertainty and growth in a cash-in-advance economy", Journal of Monetary Economics, 45(3): 631-655.

Eberhardt, M. ve Bond, Stephen. (2009) “Cross-section Dependence in Nonstationary Panel Models: A Novel Estimator", Munich Personal RePEc Archive, MPRA Paper No: 17692.

Ermisoglu, E. ve Kanık, B. (2013) “Turkish Economic Policy Uncertainty Index" Munich Personal RePEc Archive, MPRA Paper No: 49920.

Ferrara, L. ve Guérin, P. (2016) “What are the macroeconomic effects of high-frequency uncertainty shocks", Bank of Canada Staff Working Paper No: 2016-25.

Göçer, I., Mercan, M., Hotunluoğlu, H. (2012) "Seçilmiş OECD Ülkelerinde Cari İşlemler Açığının Sürdürülebilirliği: Yatay Kesit Bağımlılığı Altında Çoklu Yapısal Kırılmalı Panel Veri Analizi", Maliye Dergisi, 163, 449-470.

Hadri, K. (2000) "Testing for Stationarity in Heterogeneous Panels", Econometrics Journal, 3, 148161.

Hadri, K. ve Kurozumi, E. (2012) "A Simple Panel Stationarity Test in the Presence of Serial Correlation and a Common Factor", Economics Letters, 115, 31-34. 
Im, K. S., Pesaran, M. H. ve Shin, Y. (2003) "Testing for Unit Roots in Heterogeneous Panels". Journal of Econometrics, 115(1): 53-74.

Istrefi, K. ve Piloiu, A. (2015) "Economic Policy Uncertainty and Inflation Expectations" Society for Economic Measurement Annual Conference. Paper No: 39. http://repository.cmu.edu/sem_conf/2015/ full_schedule/39 (04.28.2017)

Johansen, S. (1988) "Statistical Analysis of Cointegration Vectors", Journal of Economic Dynamics and Control, 12(2): 231-254.

Jurado, K., Ludvigson, S. C. ve Ng, S. (2015) “Measuring Uncertainty", American Economic Review, 105(3):11771216.

Kao, C. (1999) "Spurious Regression and ResidualBased Tests for Cointegration in Panel Data", Journal of Econometrics, 90(1): 1-44.

Levin, A., Lin, C. F. ve Chu, C. S. J. (2002) "Unit Root Tests in Panel Data: Asymptotic and Finite-Sample Properties", Journal of Econometrics, 108(1): 1-24.

Lovato, Clara (2013) "On the impact of economic policy uncertainty shocks on macroeconomic expectations in the United States", Anno Accademico, 2012/13

Menyah, K., Nazlıoğlu, Ş. ve Wolde-Rufael, Y. (2014) "Financial Development, Trade Openness and Economic Growth in African Countries: New Insights from a Panel Causality Approach", Economic Modelling, 37, 386-394.

Pedroni, P. (1999) "Critical Values for Cointegration Tests in Heterogeneous Panels with Multiple Regressors", Oxford Bulletin of Economics and Statistics, 61(1): 653-670.

Pesaran, M. H. (2004) "General Diagnostic Tests for Cross Section Dependence in Panels", Center for Economic Studies \& Ifo Institute for Economic Research, CESifo Working Paper No: 1229.

Pesaran, M. H. (2007) “A Simple Panel Unit Root Test in The Presence of Cross-Section Dependence", Journal of Applied Econometrics, 22(2): 265-312.

Pesaran, M. H., Ullah, A. ve Yamagata, T. (2008) "A Bias-Adjusted LM Test of Error Cross-Section Independence", The Econometrics Journal, 11(1): 105127.
Rossi, B. ve Sekhposyan, T. (2015) "Macroeconomic Uncertainty Indices Based on Nowcast and Forecast Error Distributions", American Economic Review, 105(5): 650-55.

Sağlam, Y., Egeli, H. A. ve Egeli, P. (2017) "Gelişmiş ve Gelişmekte Olan Ülkelerde Ar\&Ge Harcamaları ve Ekonomik Büyüme Arasındaki İlişki: Panel Veri Analizi", Sosyoekonomi, 25(31): 149-165.

Scotti, C. (2013) "Surprise and Uncertainty Indexes: Real-Time Aggregation of Real-Activity Macro Surprises". Mimeo.

Stockhammar, P. ve Österholm P. (2014) "Effects of US Policy Uncertainty on Swedish GDP Growth", National Institute of Economic Research, NIER Working Paper No: 135.

Stockhammar, P. ve Österholm P. (2016) "The Impact of US Uncertainty Shocks on Small Open Economies", Open Economies Review, 1-22.

Tarı, R. (2010) Ekonometri, 6. Baskı, Kocaeli, Umuttepe Yayınları.

Tatoğlu, F. Y. (2013) Illeri Panel Veri Analizi-Stata Uygulamalı, 2. Baskı, İstanbul, Beta.

Taylor, M. P. ve Sarno, L. (1998) "The Behavior of Real Exchange Rates During The Post-Bretton Woods Period", Journal of International Economics, 46(2): 281312.

TCKB, (2016) “Dünya Ekonomisindeki Son Gelişmeler Bülteni", Türkiye Cumhuriyeti Kalkınma Bakanlığı, Ekonomik Modeller ve Stratejik Araştırmalar Genel Müdürlüğü Küresel Ekonomik Gelişmeleri İzleme Değerlendirme Dairesi.

TMB, (2016) "Inşaat Sektörü Analizi, Tünelin Girişinde Dünya-Türkiye-Inşaat Sektörü", Türkiye Müteahhitler Birliği.

Westerlund, J. (2008) "Panel Cointegration Tests of the Fisher Effect", Journal of Applied Econometrics, 23(2): 193-233.

Westerlund, J. ve Edgerton, D. L. (2007) "A Panel Bootstrap Cointegration Test", Economics Letters, 97(3): 185-190.

Wongi, K. (2016) “Economic Policy Uncertainty and Its Implication on Economic Recovery A Case Study of Korea", Korea Institute for International Economic Policy, KIEP Opinions. 


\section{Son Notlar}

'Bu kapsamdaki çalışmalarda, ulusal hisse senedi fiyat endeksleri ile Standard and Poor's tarafından Amerika birleşik devletleri hisse senedi piyasasında faaliyette bulunan en büyük 500 şirketin ağırlıklı ortalamasıyla oluşturulan S\&P 500 endeksi kullanılmaktadır.

${ }^{2}$ Bu çalışmada kapsanan ülkeler: $A B D$ ve Euro alanındaki ülkelerdir.

${ }^{3}$ Bu çalışmada kapsanan ülkeler: Avustralya, Kanada, Danimarka, Finlandiya, İzlanda, Yeni Zelanda, Norveç, İsveç ve İngiltere şeklindedir.

${ }^{4}$ Çalışmada inceleme döneminin 1997 yılı ile başlatılmasında ilgili veri tabanından elde edilen EPU Endeksi verilerinin bazı ülkeler için bu tarihten itibaren temin edilebilmeleri etkili olmuştur. Bununla birlikte, çalışmanın G+7-BRC ülkelerini kapsamasında ilgili veri tabanından elde edilen EPU Endeksi verilerinin çalışma dönemi itibariyle sadece bu ülkeler için kesintisiz bir şekilde erişilebilir olması etkin olmuştur. Bununla birlikte, çalışmanın G-7+BRC ülkelerini kapsamasında ilgili veri tabanından elde edilen EPU Endeksi verilerinin çalışma dönemi itibariyle bu ülkeler için kesintisiz bir şekilde erişilebilir olması ve bu ülkelerin 2016 yılı Nominal GSYiH sınıflandırmalarına göre dünyanın en büyük ilk 11 ekonomisi arasında bulunması etkin olmuştur.

${ }^{5} 2016$ yılı itibariyle gelişmiş ve gelişmekte olan 20 ülke için hesaplanabilen EPU genel ve alt endekslerinin kapsamı ve hesaplanma yöntemi hakkında ayrıntılı bilgi için bakınız: (Baker vd., 2015: 1-72).

${ }^{6}$ RGSYIH değişkeni, ilgili veri tabanından 2011 yılı fiyatlarıyla ve ABD doları (USD) olarak satın alma gücü paritesi cinsinden alınmıştır. RSSER değişkeni, ilgili veri tabanından 2010 yılı fiyatlarıyla ve ABD doları (USD) olarak temin edilmiştir. Beşeri sermayeyi nitelik boyutuyla temsil eden EE değişkeni; aktif nüfusun ilk, orta ve yükseköğretim kademelerindeki ortalama okullaşma yılı ve aynı eğitim kademelerindeki getiri oranlarına dayalı olarak kişi başına düşen değerler cinsinden hesaplanmaktadır.

${ }^{7}$ Çalışmada tanımlanan modellerin tahmininde Gauss 10.0 ve Stata 14.00 ekonometri paket programları kullanılmıştır. 
